\title{
Akumulasi Besi (Fe) pada Kerang Hijau di Perairan Tanjung Mas, Semarang
}

\section{(Accumulation of Iron (Fe) in Green Mussel (Perna viridis Linnaeus 1758) in Tanjung Mas Waters, Semarang)}

\author{
Findiani Dwi Astari ${ }^{1 *}$, Djamar Tumpal Floranthus Lumban Batu ${ }^{2}$, Isdradjad Setyobudiandi
}

(Diterima Februari 2020/Disetujui Desember 2020)

\begin{abstract}
ABSTRAK
Sumber logam besi (Fe) di perairan dapat berasal dari berbagai kegiatan manusia, seperti kegiatan rumah tangga dan kegiatan industri. Kerang hijau yang mengandung Fe sangat membahayakan bagi kerang itu sendiri dan bagi kesehatan manusia apabila dikonsumsi secara berlebihan. Penelitian ini bertujuan untuk menganalisis konsentrasi Fe pada daging kerang hijau, menentukan batas aman daging kerang hijau untuk dikonsumsi oleh manusia, dan menghitung nilai faktor biokonsentrasi. Penelitian ini dilakukan di Perairan Tanjung Mas, Semarang. Sampel yang diambil berupa kerang hijau, sedimen, dan air kemudian dianalisis kandungan besi dengan Spektrofotometer Serapan Atom. Hasil penelitian menunjukkan rentang nilai konsentrasi Fe pada kerang hijau dari bulan Juli hingga November 2019 adalah sebesar 39-283,97 mg/kg. Nilai MTI untuk orang dewasa berkisar antara 1,18-4,92 kg, sedangkan untuk anak-anak berkisar antara 0,24-0,98 kg. Nilai faktor biokonsentrasi kerang hijau dan air adalah 3271 - 24839, sedangkan nilai faktor biokonsentrasi kerang hijau dan sedimen adalah 0,010-9,647.
\end{abstract}

Kata kunci: besi, biokonsentrasi, kerang hijau, maximum tolerable intake, Tanjung Mas

\section{ABSTRACT}

The source of iron in waters can come from human activities that carry out activities such as waste disposal in household and industrial activities. Green mussels containing iron are very dangerous for the shells themselves and for human health if consumed in excess. This study aims to analyze the concentration of iron in green mussel meat, determine the safe limit of green mussel meat for consumption by humans, and calculate the value of bioconcentration factors. This research was conducted in the sea of Tanjung Mas, Semarang. Samples taken in the form of green mussels, sediments, and water were then analyzed for iron concentrations with Atomic Absorption Spectrophotometer. The results of the study showed that the range of iron concentration values in green mussels from July to November was 39-283,97 mg/kg. The range of MTI values for adults was 1.18-4.92, while for children the

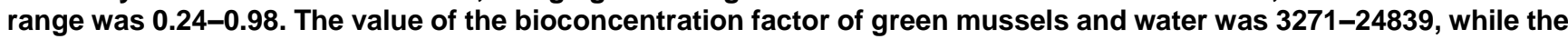
value of the bioconcentration factor of green mussels and sediments was 0.010-9.647.

Keywords: bioconcentration, green mussels, iron, maximum tolerable intake, Tanjung Mas

\section{PENDAHULUAN}

Perkembangan wilayah pesisir di kawasan Tanjung Mas dari tahun ke tahun meningkat pesat. Terdapat industri yang bergerak di bidang Pembangkit Listrik Tenaga Uap. Kegiatan PLTU menggunakan batubara sebagai bahan utama. Batubara sendiri mengandung pirit yang merupakan mineral sulfida di mana pirit memiliki komposisi besi (Fe). Adanya uap yang merupakan hasil pembakaran batubara akan diarahkan untuk memutar turbin sehingga menghasilkan daya mekanik berupa putaran dan putaran tersebut akan menghasilkan energi listrik. Turbin yang berputar

\footnotetext{
1 Sekolah Pascasarjana, Program Studi Pengelolaan Sumberdaya Perairan, Institut Pertanian Bogor, Kampus IPB Darmaga, Bogor 16680

2 Departemen Manajemen Sumberdaya Perairan, Fakultas Perikanan dan IImu Kelautan, Institut Pertanian Bogor, Kampus IPB Darmaga, Bogor 16680

* Penulis Korespondensi: Email: findianiastari@gmail.com
}

akan mengeluarkan uap pada terminal output generator di mana uap tersebut akan dimasukkan ke kondensor untuk didinginkan dengan air pendingin. Pembangkit listrik ini menggunakan air laut sebagai air pendingin yang berfungsi untuk mengambil kalor dari kondensor sehingga air pendingin tersebut mengalami kenaikan suhu yang kemudian dibuang kembali ke perairan laut dalam bentuk limbah panas yang mengandung banyak unsur kimia, salah satunya besi. Apabila sisa limbah tersebut tidak diolah terlebih dahulu dan kemudian dibuang begitu saja ke perairan bebas maka akan terjadi penurunan kualitas perairan atau dapat dianggap tercemar. Selain menurunkan kualitas perairan, limbah dapat terakumulasi di sedimen melalui beberapa proses fisika kimia yang selanjutnya akan menyebabkan pelepasan bahan toksik dari sedimen ke organisme. Limbah buangan atau bahan toksik tersebut diperkirakan mengandung logam. Salah satu logam yang terdapat di limbah hasil produksi ialah logam besi (Permanawati et al. 2013). 
Sejauh ini, pencemaran perairan akibat adanya logam Fe menjadi masalah untuk kelangsungan hidup biota air laut, seperti kerang hijau. Kerang hijau merupakan biota filter feeder yang mengambil makanannya dengan cara menyaring air. Cara makan yang demikian membuat berbagai komponen bahanbahan akan masuk ke dalam tubuh kerang tersebut (Liliandari dan Aunurohim, 2013). Penelitian mengenai konsentrasi besi pada kerang hijau di Perairan Tanjung Mas sebelumnya telah dilakukan oleh Supriyantini \& Endrawati (2015). Hasilnya menunjukkan bahwa konsentrasi Fe pada kerang hijau sebesar 26,727$203,596 \mathrm{mg} / \mathrm{kg}$. Akan tetapi, sebagian besar peneliti belum mengkaji jaminan keamanan pangan dan kesehatan kerang hijau. Kerang hijau yang mengandung $\mathrm{Fe}$ sangat membahayakan bagi kesehatan manusia apabila dikonsumsi secara berlebihan. Unsur Fe memang dibutuhkan organisme laut untuk pertumbuhan dan perkembangan hidupnya. Akan tetapi, besi dapat terakumulasi di dalam tubuh organisme jika terjadi absorbsi terus menerus dan dalam jumlah berlebih $\mathrm{Fe}$ dapat bersifat racun. Keracunan logam $\mathrm{Fe}$ dalam jangka pendek dapat mengakibatkan rasa mual, muntah, diare, dan sakit kepala (Suryaningsih et al. 2018). Tujuan penelitian ini adalah untuk mempelajari informasi mengenai konsentrasi $\mathrm{Fe}$ yang terkandung dalam air laut, sedimen, dan daging kerang hijau (Perna viridis L.) dan keterkaitan konsentrasi $\mathrm{Fe}$ pada tiga komponen tersebut serta menentukan batas aman konsumsi kerang hijau bagi manusia (orang dewasa dan anakanak), dan tingkat akumulasi besi pada kerang hijau (Perna viridis L.).

\section{METODE PENELITIAN}

Penelitian mengenai kandungan besi ( $\mathrm{Fe}$ ) pada kerang hijau ini dilakukan di Perairan kawasan Pelabuhan Tanjung Mas. Penelitian dilaksanakan pada bulan Juli hingga Oktober 2019, yang disesuaikan dengan waktu panen kerang yang dibudidaya oleh nelayan. Observasi dilakukan sebanyak dua kali, yaitu pada bulan April dan Mei 2019. Hewan uji yang diamati adalah kerang hijau (Perna viridis L.). Analisis konsentrasi besi $(\mathrm{Fe})$ pada daging kerang hijau dilakukan di Balai Besar Teknologi Pencegahan Pencemaran Industri (BBTPPI) Semarang, sedangkan pada air laut dan sedimen dilakukan di Laboratorium Kesehatan dan Pengujian Alat Kesehatan Kota Semarang.

Terdapat 3 stasiun pada penelitian ini yang ditentukan berdasarkan daerah pengambilan kerang hijau yang dibudidaya atau dipelihara pada bambu oleh nelayan. Stasiun 1 berada di sebelah timur Pelabuhan Tanjung Mas yang berjarak sekitar 4 mil dari pantai, sedangkan stasiun 2 dan stasiun 3 berada di sebelah utara permukiman warga Tambak Lorok, Semarang yang berjarak sekitar 5 mil dari pantai. Lokasi penelitian disajikan pada Gambar 1.

\section{Bahan dan Alat}

Alat yang digunakan dalam penelitian ini di antaranya adalah GPS (Global Positioning System), botol sampel, jangka sorong (dengan ketelitian 0,01 $\mathrm{mm}$ ), timbangan digital (dengan ketelitian 0,01 g), kertas label, handrefractometer, DO meter, $\mathrm{pH}$ meter, ATK, dan coolbox. Bahan yang digunakan dalam penelitian ini meliputi kerang hijau, air laut, dan

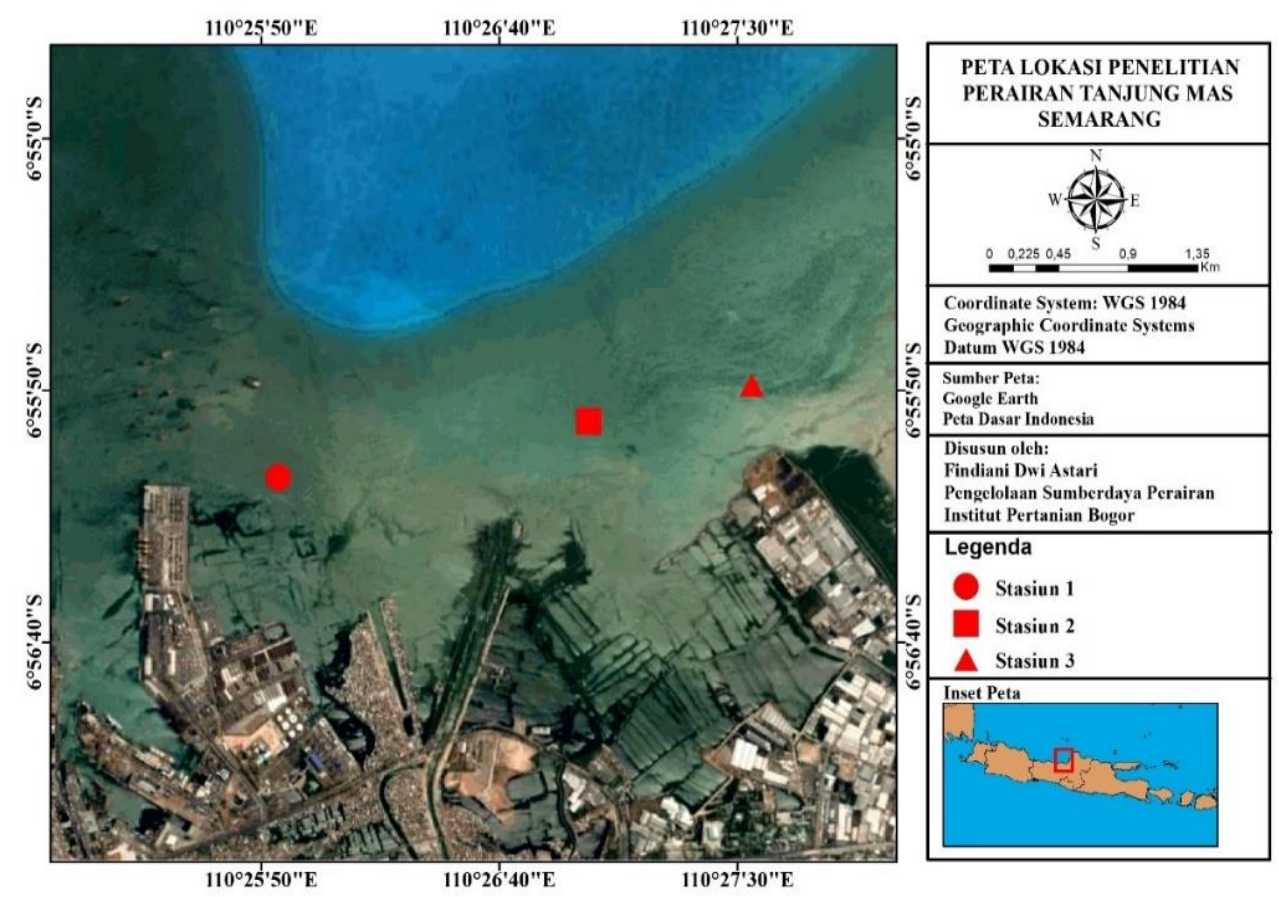

Gambar 1 Lokasi penelitian pada tiga stasiun di Perairan Tanjung Mas, Semarang. 
sedimen yang diambil dari perairan di sekitar Pelabuhan Tanjung Mas, es kristal, dan aquades.

\section{Pengambilan Daging dan Pengukuran Logam Fe pada Kerang Hijau}

Pengambilan sampel kerang hijau dilakukan dengan metode acak berstrata, yaitu pengambilan sampel dengan memperhatikan tingkatan di dalam suatu populasi. Kerang yang diambil merupakan kerang yang dipelihara oleh nelayan di lokasi dengan bambu tancap sebagai media pemeliharaan. Kerang hijau yang menempel pada bambu diambil secara acak berdasarkan kelompok ukuran kerang yang telah ditentukan. Kelompok ukuran tersebut terdiri atas tiga kelompok berdasarkan ukuran panjang cangkang, yaitu kecil $(3-4,59 \mathrm{~cm})$, sedang $(4,6-6 \mathrm{~cm})$, dan besar $(>6 \mathrm{~cm})$ (Tantanasarit et al. 2013). Proses pengambilan sampel dibantu oleh nelayan dengan mengambil langsung menggunakan tangan. Jumlah sampel kerang yang diambil pada masing masing stasiun ialah 120 kerang untuk kelompok ukuran kecil, 100 kerang untuk kelompok ukuran sedang, dan 80 kerang untuk kelompok ukuran besar. Sampel kerang yang telah diambil, diukur panjang cangkangnya menggunakan jangka sorong dan dikelompokkan menjadi tiga ukuran tersebut di atas, yaitu ukuran kecil, ukuran sedang, dan ukuran besar.

Pengukuran logam Fe merujuk pada metode SNI 01-2896-1992. Sampel diambil dari dalam wadah polystyrene sebanyak 5 gram untuk ditimbang dalam cawan porselen. Sampel diuapkan di atas hot plate pada suhu $100^{\circ} \mathrm{C}$, kemudian sampel dimasukkan ke dalam tungku di pengabuan. Suhu tungku pengabuan dinaikkan secara bertahap mulai $100^{\circ} \mathrm{C}$ setiap 30 menit hingga mencapai $450 \stackrel{\circ}{ } \mathrm{C}$ dan dipertahankan selama 18 jam. Sampel dikeluarkan dari tungku pengabuan dan didinginkan pada suhu ruang, ditambahkan $1 \mathrm{~mL}$ HNO3 (konsentrasi 52\%), kemudian diuapkan di atas hot plate pada suhu $100^{\circ} \mathrm{C}$ sampai kering. Setelah kering, bahan dimasukkan kembali ke dalam tungku pengabuan dan suhu dinaikkan secara bertahap mulai $100^{\circ} \mathrm{C}$ setiap 30 menit hingga mencapai $450^{\circ} \mathrm{C}$ dan dipertahankan selama tiga jam. Sampel didinginkan pada suhu ruang kemudian ditambahkan $5 \mathrm{~mL} \mathrm{HCl}$ (konsentrasi 18\%) dan selanjutnya ditambahkan $10 \mathrm{~mL}$ HNO3. Sampel dipindahkan ke dalam labu takar polypropylene $50 \mathrm{~mL}$ dan ditambahkan $\mathrm{HNO} 3$ sampai tepat mencapai tanda batas. Sampel sejumlah $10 \mathrm{~mL}$ kemudian digunakan untuk pengukuran $\mathrm{Fe}$ dengan AAS dengan gelombang resonansi $248,3 \mathrm{~nm}$.

\section{Pengukuran logam Fe pada air dan sedimen}

Analisis logam Fe pada sampel air merujuk pada metode SNI 06-6989.4-2004. Sampel air laut yang diperoleh disiapkan untuk dianalisis kandungan logam Fe. Sampel disaring dengan kertas saring ukuran pori 0,45 mikrometer dan ditambahkan $\mathrm{HNO} 3$ (konsentrasi $52 \%$ ) sebanyak $5 \mathrm{~mL}$. Setelah itu dipanaskan sampai sisa volume $15 \mathrm{~mL}$. Sampel dipindahkan ke dalam labu ukur $100 \mathrm{~mL}$ dan ditambah akuades sampai tepat tanda tera kemudian dihomogenkan. Selanjutnya sampel sejumlah $10 \mathrm{~mL}$ diukur dengan spektrofotometer serapan atom dengan gelombang resonansi $248,3 \mathrm{~nm}$.

Analisis logam Fe pada sampel sedimen diukur dengan merujuk pada metode APHA (2012). Sampel yang diperoleh dikeringkan dalam oven pada temperatur $105^{\circ} \mathrm{C}$, kemudian dihaluskan dan diayak. Sampel ditimbang sebanyak $5 \mathrm{~g}$ kemudian dipindahkan ke erlenmeyer $250 \mathrm{~mL}$. Selanjutnya sampel ditambahkan $\mathrm{HNO} 3$ sebanyak $5 \mathrm{~mL}$ dan akuades $50 \mathrm{~mL}$, kemudian didestruksi dalam pemanas listrik hingga diperoleh larutan jernih sampai volumenya menjadi $10 \mathrm{~mL}$. Sampel disaring dengan kertas saring Whatman No. 41 dan hasil saringan diencerkan hingga $50 \mathrm{~mL}$. Sampel sejumlah $10 \mathrm{~mL}$ digunakan untuk mengukur kadar logam $\mathrm{Fe}$ dengan menggunakan Spektrofotometer Serapan Atom pada gelombang resonansi $248,3 \mathrm{~nm}$.

\section{Analisis Data}

Data konsentrasi logam Fe pada air, sedimen, dan kerang hijau ditampilkan dalam bentuk grafik dan dilakukan analisis regresi sederhana untuk melihat nilai laju konsentrasi logam Fe. Analisis data yang dilakukan meliputi penentuan batas aman konsumsi dan faktor biokonsentrasi.

\section{Penentuan Batas Aman Konsumsi}

Batas aman konsumsi kerang hijau meliputi Maximum Weekly Intake (MWI) dan Maximum Tolerable Intake (MTI). Batas maksimum konsentrasi bahan pangan terkonsentrasi logam berat yang boleh dikonsumsi dalam satu minggu (Maksimum Weekly Intake, $M W I$ ) menggunakan angka ambang batas yang diterbitkan oleh organisasi dan lembaga pangan internasional World Health Organisation (WHO) dan Joint FAO/WHO Expert Committee on Food Additive (JEFCA) (2004). Perhitungan Maksimum Weekly Intake menggunakan rumus (Mirawati et al., 2016) :

$$
\text { MWI }(g)=\text { Bobot Badan a) } \times \text { PTWI b) }
$$

\section{Keterangan:}

a) Rata-rata bobot badan, untuk orang dewasa $50 \mathrm{~kg}$, untuk anak-anak adalah $15 \mathrm{~kg}$

b) PTWI: Provisional Tolerable Weekly Intake (angka toleransi maksimum asupan per minggu)

Provisional Tolerable Weekly Intake (PTWI) adalah jumlah asupan kontaminan logam berat pada makanan yang dapat ditoleransi untuk seminggu sehingga tidak membahayakan kesehatan. Nilai PTWI untuk Fe sebesar 5,6 mg/kg BB (Ahmed et al. 2015). Penentuan batas aman konsumsi dilakukan dengan mengacu pada nilai PTWI sehingga diperoleh batas aman kerang hijau yang boleh dikonsumsi. Nilai angka toleransi asupan maksimum (Maximum Tolerable Intake, MTI) dihitung dengan menggunakan rumus sebagai berikut (Mirawati et al. 2016): 


$$
\mathrm{MTI}=\frac{\mathrm{MWI}}{\mathrm{Ct}}
$$

Keterangan:

$\mathrm{MWI}=$ Maximum Weekly Intake (untuk orang dewasa $(50 \mathrm{~kg})$ dan anak-anak $(15 \mathrm{~kg})$ per minggu, dalam satuan $\mathrm{mg}$;

$\mathrm{Ct}=$ Konsentrasi logam berat yang ditemukan di dalam jaringan lunak kerang $(\mathrm{mg} / \mathrm{kg})$.

\section{Faktor biokonsentrasi (FBK)}

Faktor biokonsentrasi (Bioconcentration Factor, BCF) digunakan untuk mengetahui kemampuan kerang hijau dalam mengakumulasi logam berat dari air dan sedimen. Faktor biokonsentrasi dapat dihitung menggunakan rumus sebagai berikut (Irawati et al., 2018):

$$
\begin{aligned}
& \text { BCF (o-w) }=\frac{C \text { org }}{C \text { water }} \\
& \text { BCF (o-sed) }=\frac{C \text { org }}{C \text { sed }}
\end{aligned}
$$

Keterangan:

$$
\begin{array}{ll}
\mathrm{BCF}(\mathrm{o}-\mathrm{w}) & \begin{array}{c}
=\text { Faktor biokonsentrasi (organisme } \\
\text { dengan air) }
\end{array} \\
\mathrm{BCF}(\mathrm{o}-\mathrm{sed}) & =\begin{array}{l}
\text { Faktor biokonsentrasi (organisme } \\
\text { dengan sedimen) }
\end{array} \\
\mathrm{C} \text { org } & \begin{array}{l}
\text { Konsentrasi logam berat dalam } \\
\text { organisme }(\mathrm{mg} / \mathrm{kg})
\end{array} \\
\mathrm{C} \text { water } & \begin{array}{l}
\text { Konsentrasi logam berat dalam air } \\
(\mathrm{mg} / \mathrm{L})
\end{array} \\
\mathrm{C} \text { sed } & \begin{array}{l}
\text { Konsentrasi logam berat dalam } \\
\text { sedimen }(\mathrm{mg} / \mathrm{kg})
\end{array}
\end{array}
$$

Hasil perhitungan faktor biokonsentrasi (FBK) dilanjutkan dengan mengklasifikasikan ke dalam kategori tingkat akumulasi berdasarkan (LaGrega et al. 2001) yaitu:

$$
\begin{array}{ll}
\text { Akumulasi rendah } & : \text { FBK }<100 \\
\text { Akumulasi sedang } & : 100<\text { FBK } \leq 1000 \\
\text { Akumulasi tinggi } & : \text { FBK }>1000 \text { FBK }
\end{array}
$$

\section{HASIL DAN PEMBAHASAN}

\section{Konsentrasi Fe Pada Kerang Hijau}

Konsentrasi logam Fe dalam tubuh kerang hijau berfluktuasi dan mengalami penurunan dari bulan Juli hingga Oktober dan mengalami sedikit peningkatan pada bulan November. Fluktuasi ini disebabkan oleh dua faktor, yaitu faktor internal dan faktor eksternal. Faktor internal tersebut didasarkan pada ukuran biota Perna viridis, sistem kerja enzim di dalam tubuh biota, dan kemampuan biota pada saat melepaskan kontaminan yang disebut sebagai proses depurasi. Menurut Budiawan et al. (2019) proses depurasi bahan toksik pada kerang hijau paling cepat dikeluarkan dari organ pencernaan, yaitu sekitar $50 \%$, sedangkan paling lambat dikeluarkan dari organ insang, yaitu sekitar $5 \%$. Perbedaan ini terjadi karena pada organ pencernaan terdapat metallothionein yang berperan sebagai pengikat logam berat. Molekul metallothionein bersifat ringan dan mudah larut (Cytosolid). Bagian dari metallothionein berupa thiol yang kaya protein karena mengandung asam amino yang mampu berikatan dengan logam berat. Pada organ insang, proses depurasi lebih lambat dibadingkan dengan organ pencernaan. Perbedaan ini diduga karena di dalam organ insang metallothionein lebih sedikit kandungannya dibandingkan dengan organ pencernaan. Proses depurasi tersebut berlangsung dengan cepat selama 3 hari, lalu pada hari keempat dan selanjutnya proses depurasi mulai melambat. Oleh karena itu, penurunan konsentrasi logam Fe secara signifikan yang terjadi dari bulan Juli ke bulan September dan Oktober diduga mengalami proses depurasi yang puncaknya berlangsung pada hari pertama hingga hari ketiga setelah proses bioakumulasi di dalam tubuh kerang hijau. Faktor eksternal ialah kondisi fisik lingkungan, yaitu parameter fisika dan kimia yang sangat berpengaruh dalam hal ini adalah suhu, salinitas, dan DO. Nilai konsentrasi $\mathrm{Fe}$ pada kerang hijau disajikan pada Gambar 2.

\section{Konsentrasi Fe Pada Sedimen}

Nilai konsentrasi $\mathrm{Fe}$ pada sedimen paling tinggi terdapat pada bulan Juli, sedangkan konsentrasi terendah ditemukan pada bulan September. Konsentrasi logam Fe secara kesuluruhan dari bulan Juli hingga Oktober memiliki nilai yang tertinggi pada stasiun 1. Hal ini karena lokasi stasiun 1 yang paling dekat dengan Pelabuhan Tanjung Mas. Aktivitas di pelabuhan dan jumlah kapal kapal muatan yang menghasilkan limbah berupa logam Fe diduga menjadi faktor yang mempengaruhi kandungan logam Fe yang tinggi pada sedimen. Kandungan logam $\mathrm{Fe}$ pada sedimen di semua stasiun diketahui lebih tinggi dibandingkan logam $\mathrm{Fe}$ pada air laut. Hal ini disebabkan karena adanya proses sedimentasi yang dialami oleh logam Fe. Menurut Wulandari (2012), sifat sedimen sebagai nutrient trap, oleh karena itu logam $\mathrm{Fe}$ yang semula terlarut dalam air laut akan terendapkan di sedimen. Hal ini menunjukkan adanya akumulasi logam berat dalam sedimen. Kadar logam berat $\mathrm{Fe}$ yang rendah dalam air laut bila dibandingkan dengan sedimen bukan berarti logam Fe tidak memiliki dampak negatif pada perairan, namun lebih disebabkan karena kemampuan perairan tersebut yang cukup besar untuk mengencerkan bahan toksik. Menurut Rochyatun et al. (2006), proses pengendapan logam berat pada sedimen terjadi karena massa jenis logam yang lebih tinggi dibandingkan dengan massa jenis air. Nilai konsentrasi Fe pada sedimen disajikan pada Gambar 3. 
Juli

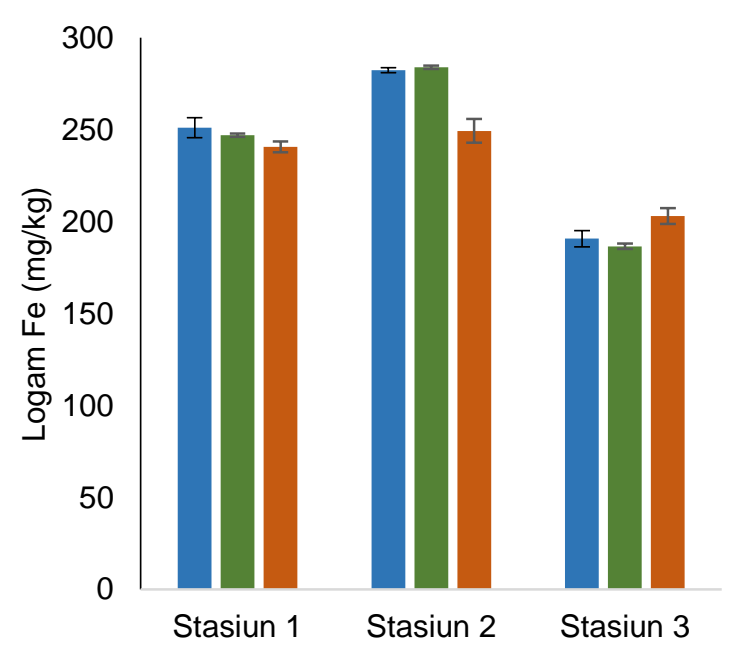

Oktober

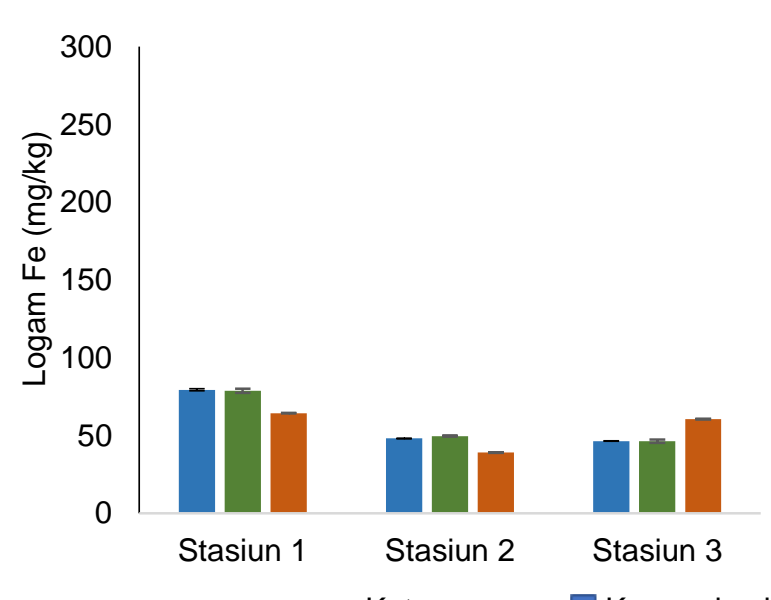

Keterangan: $\square$ Kerang kecil $\square$ Kerang sedang Kerang besar
September
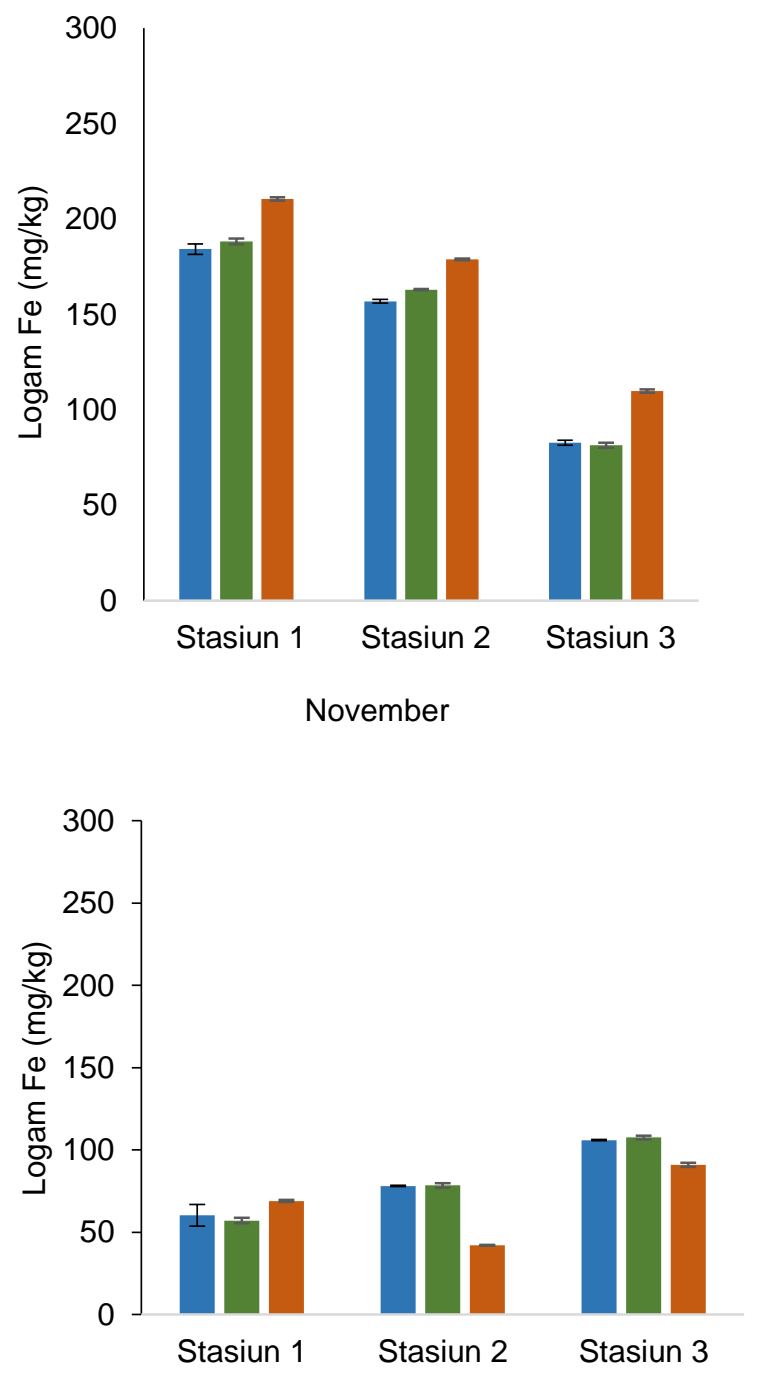

\section{$(3-4,59 \mathrm{~cm}) \quad(4,6-6 \mathrm{~cm}) \quad(>6 \mathrm{~cm})$}

Gambar 2 Konsentrasi logam Fe pada daging kerang hijau pada bulan Juli, September, Oktober, dan November 2019 di Perairan Tanjung Mas, Semarang.

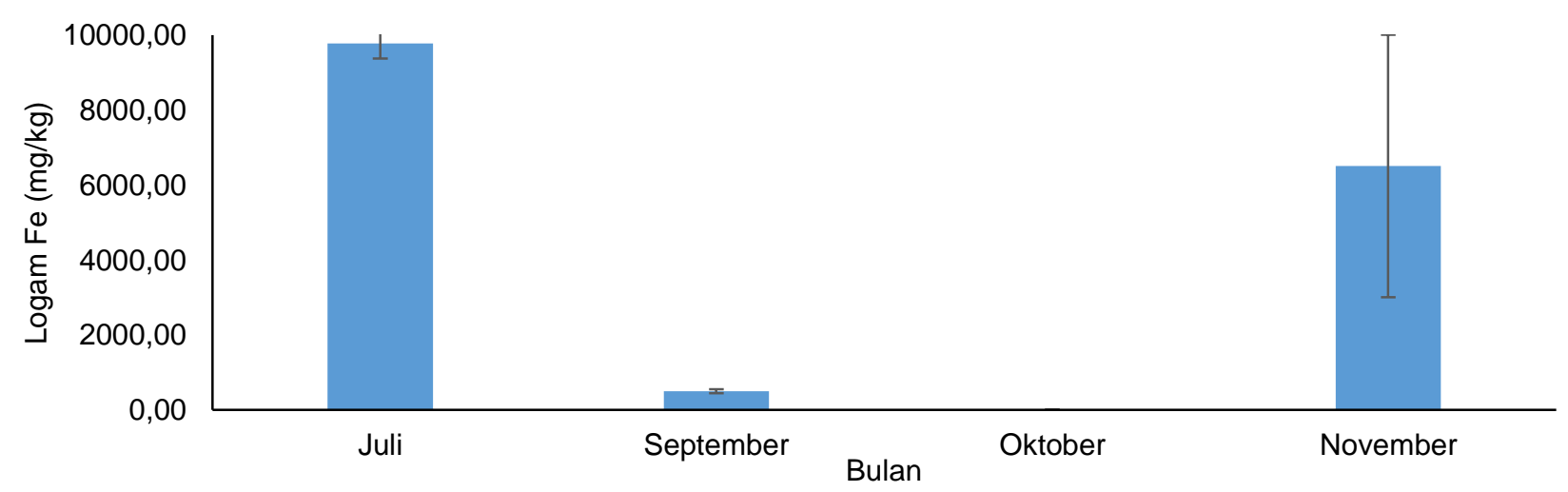

Gambar 3 Konsentrasi logam Fe pada sedimen pada bulan Juli, September, Oktober, dan November 2019 di Perairan Tanjung Mas, Semarang. 


\section{Konsentrasi Fe Pada Air Laut}

Nilai konsentrasi logam $\mathrm{Fe}$ pada air laut yang cenderung rendah diduga dipengaruhi oleh faktor fisika dan kimia. Salah satu faktor fisika yang mempengaruhi adalah pasang surut. Hal ini diperkuat oleh Wardani et al. (2014) yang menyatakan bahwa pada air laut, logam berat masih bisa bergerak bebas akibat pasang surut sehingga terjadi pengenceran. Faktor lain yang mempengaruhi ialah logam Fe yang masuk ke perairan mengalami proses sedimentasi di mana logam berat akan diserap oleh partikel-partikel tersuspensi.

Kandungan logam berat dalam perairan secara alamiah berada dalam jumlah yang relatif sedikit. Akan tetapi, dengan adanya aktivitas masyarakat di sekitar Perairan Tanjung Mas, seperti kegiatan industri, domestik, dan lainnya dapat menjadi faktor penyebab peningkatan kandungan logam berat. Menurut Kamarati et al. (2018), adanya peningkatan serta kontinuitas buangan air limbah industri yang mengandung senyawa logam besi, cepat atau lambat akan merusak ekosistem di laut. Hal ini disebabkan karena logam berat sukar mengalami pelapukan, baik secara fisika, kimia, maupun biologis. Nilai konsentrasi Fe pada air laut disajikan pada Gambar 4.

\section{Nilai Maximum Tolerable Intake}

Batas aman konsumsi kerang hijau dalam satu minggu dihitung berdasarkan hasil perolehan data konsentrasi logam Fe pada kerang hijau dengan menggunakan rumus MTI. Nilai MTI dapat diketahui dengan terlebih dahulu menghitung nilai Maximum Weekly Intake (MWI). Nilai MWI dihitung dengan menganggap bobot untuk orang dewasa sebesar $50 \mathrm{~kg}$ dan bobot anak-anak sebesar $15 \mathrm{~kg}$. Hasil perhitungan Maximum Weekly Intake disajikan pada Tabel 1 dan 2.

Nilai MTI tertinggi untuk orang dewasa dan anak anak berada pada bulan Oktober, sedangkan nilai MTI terendah untuk orang dewasa dan anak anak berada pada bulan Juli. Hal ini disebabkan nilai konsentrasi logam Fe pada kerang hijau di bulan Juli paling tinggi, yaitu rata rata sebesar $237,17 \mathrm{mg} / \mathrm{kg}$ dan di bulan Oktober paling rendah, yaitu rata rata sebesar 56,94. Berdasarkan hasil perhitungan MTI, masyarakat orang dewasa diperbolehkan mengkonsumsi kerang hijau paling banyak pada bulan Oktober, yaitu sebesar 4,92 $\mathrm{kg}$ dan untuk anak anak juga diperbolehkan mengkonsumsi kerang hijau paling banyak pada bulan Oktober, yaitu sebesar 0,98 kg.

Masyarakat yang secara berlebihan mengkonsumsi kerang hijau yang mengandung logam $\mathrm{Fe}$ akan berbahaya karena logam $\mathrm{Fe}$ akan terakumulasi di dalam tubuhnya. Walaupun logam Fe akan keluar dari tubuh manusia melalui proses ekskresi, jumlahnya tidak banyak. Menurut Qamariyah dan Yanti (2018), pembuangan kadar besi keluar tubuh terjadi melalui beberapa jalan, di antaranya melalui keringat $0,2-1,2$ $\mathrm{mg} /$ hari, air seni $0,1 \mathrm{mg} /$ hari, dan melalui feses $0,5-1,4$ $\mathrm{mg} / \mathrm{hari}$. Besi memiliki sifat yang tidak dapat diproduksi

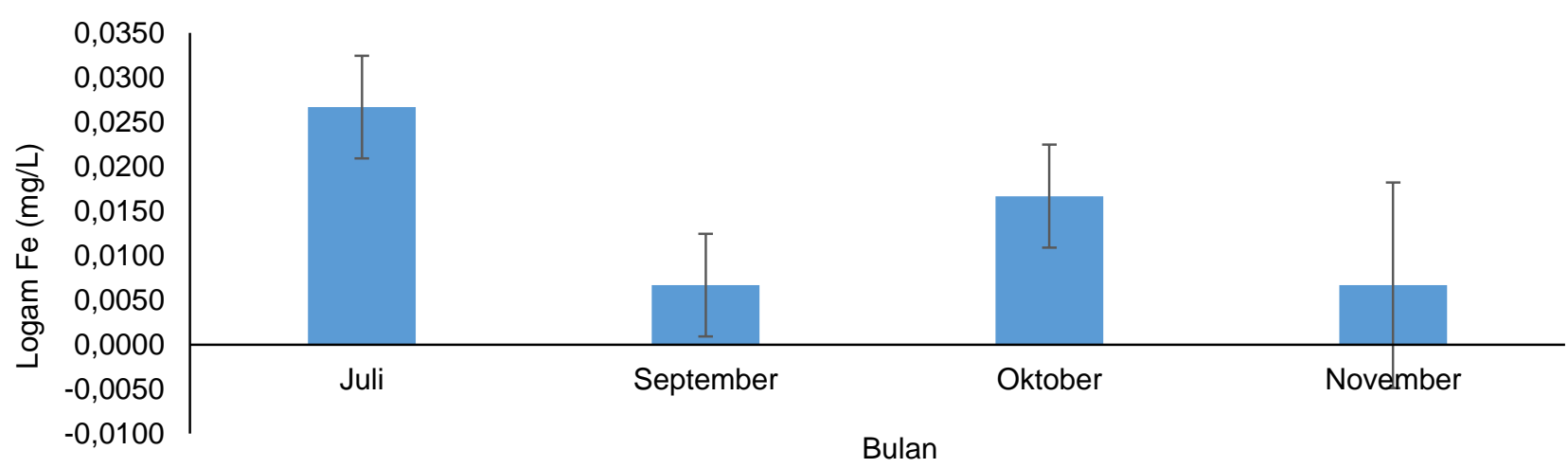

Gambar 4 Konsentrasi logam Fe pada air laut pada bulan Juli, September, Oktober, dan November 2019 di Perairan Tanjung Mas, Semarang.

Tabel 1 Nilai MWI (angka toleransi asupan per minggu) orang dewasa (50 kg) dan anak anak (15 kg). JEFCA in FAO/WHO (2004) (*). MWI (Maximum Weekly Intake). PTWI (Provisional Tolerable Weekly Intake).

\begin{tabular}{ccc}
\hline Kategori & Nilai MWI $(\mathrm{mg})$ & ${ }^{*}$ PTWI $(\mathrm{mikrogram} / \mathrm{kg})$ \\
\hline Orang dewasa $(50 \mathrm{~kg})$ & 280 & 5,6 \\
Anak-anak $(15 \mathrm{~kg})$ & 56 & 5,6 \\
\hline
\end{tabular}

Tabel 2 Nilai angka toleransi asupan bahan pangan (Maximum Tolerable Intake, MTI) untuk orang dewasa (50 kg) dan anakanak $(15 \mathrm{~kg})$

\begin{tabular}{lcc}
\hline Bulan & Nilai MTI orang dewasa $(\mathrm{kg})$ & Nilai MTI anak-anak $(\mathrm{kg})$ \\
\hline Juli & 1,18 & 0,24 \\
September & 1,86 & 0,37 \\
Oktober & 4,92 & 0,98 \\
November & 3,65 & 0,73 \\
\hline
\end{tabular}


oleh tubuh sehingga harus dicukupi kebutuhannya dari makanan yang dikonsumsi, namun jumlahnya tidak berlebihan.

\section{Faktor Biokonsentrasi (BCF)}

Faktor biokonsentrasi adalah kemampuan organisme dalam mengakumulasi logam berat dalam tubuhnya yang didefinisikan sebagai perbandingan antara konsentrasi logam berat pada lapisan tubuh organisme dan konsentrasi logam berat pada air tempat organisme tersebut terpapar. Nilai BCF dapat diperoleh dengan membandingkan kemampuan organisme (kerang) dalam menyerap logam dari air dan sedimen. Oleh karena itu, terdapat dua nilai BCF, yaitu BCF organisme-sedimen (BCFo-s) dan BCF organisme-air (BCFo-w) (Amriani et al. 2011). Faktor biokonsentrasi kerang hijau disajikan pada Tabel 3 dan Tabel 4.

Faktor biokonsentrasi organisme dan air dalam penelitian ini dari bulan Juli hingga November tergolong dalam kategori tinggi, yaitu berkisar 3271,26-24838,81, sedangkan faktor biokonsentrasi organisme dan sedimen dalam penelitian ini berada pada kategori rendah, yaitu berkisar 0,010-9,647. Faktor biokonsentrasi organisme dan sedimen tergolong rendah dikarenakan tingginya konsentrasi logam $\mathrm{Fe}$ dalam sedimen dibandingkan dengan di dalam tubuh kerang hijau. Penyerapan sedimen terhadap partikel-partikel logam lebih dominan karena logam mempunyai kecenderungan untuk berikatan dengan hidroksida dan bahan organik dalam sedimen. Sementara itu, kerang hijau yang terakumulasi logam Fe dikarenakan sifat dasar kerang hijau, yaitu filter feeder yang memperoleh makanannya dengan menyaring partikel-partikel air laut maupun sedimen untuk kelangsungan hidupnya sehingga logam berat akan terakumulasi di dalam jaringan kerang.

Logam Fe lebih mudah terakumulasi dalam kerang hijau melalui medium air dibandingkan sedimen. Hal ini terbukti dengan nilai faktor biokonsentrasi organisme dan air yang tergolong tinggi. Kemampuan suatu organisme kerang dalam mengakumulasi logam berbeda-beda. Penelitian lain mengenai nilai biokonsentrasi organisme dan sedimen dilakukan oleh Rayyan et al. (2019), yaitu di Perairan Estuari Ujung Pangkah. Hasil penelitian tersebut menunjukkan bahwa konsentrasi logam Fe dalam kerang hijau lebih rendah dibandingkan dengan konsentrasi logam $\mathrm{Fe}$ dalam sedimen sehingga nilai biokonsentrasi organisme dan sedimen tergolong rendah, yaitu dengan rata-rata 0,06 . Konsentrasi $\mathrm{Fe}$ yang tinggi dalam sedimen menunjukkan bahwa logam Fe yang terlarut dalam air laut mengalami pengendapan (sedimentasi) dalam jangka waktu yang cukup lama. Logam yang tersuspensi dalam sedimen akan lebih lama bertahan sehingga sedimen memiliki kandungan yang lebih tinggi dibandingkan dengan kandungan logam Fe dalam air laut (Amansyah \& Syarif 2014). Hasil yang sama juga didapat dari penelitian yang dilakukan oleh Amelia et al. (2019), yaitu nilai faktor biokonsentrasi kerang dan sedimen tergolong rendah, yaitu berkisar 0,16-19,47.

\section{KESIMPULAN}

Konsentrasi logam Fe pada air laut di Perairan Tanjung Mas, Semarang berada pada baku mutu, yaitu $0,0067 \mathrm{mg} / \mathrm{L}-0,0267 \mathrm{mg} / \mathrm{L}$. Konsentrasi logam Fe pada daging kerang hijau pada tiga kelompok jenis ukuran di Perairan Tanjung Mas, Semarang telah melewati ambang batas. Masyarakat tetap diperbolehkan mengkonsumsi kerang hijau yang diambil dari Perairan Tanjung Mas, Semarang selama jumlahnya tidak melebihi nilai konsumsi maksimum, yaitu sebanyak 1$4 \mathrm{~kg}$ untuk orang dewasa dan $1 \mathrm{~kg}$ untuk anak-anak sebagai acuan untuk menghindari efek negatif logam berat yang masuk ke dalam tubuh. Nilai faktor biokonsentrasi organisme dan air logam Fe lebih tinggi dibandingkan dengan biokonsentrasi organisme dan sedimen karena Fe lebih mudah terakumulasi dalam kerang hijau melalui medium air dibandingkan dengan melalui sedimen.

Tabel 3 Faktor biokonsentrasi kerang hijau (Perna viridis) dan air (BCFo-w) dari Perairan Tanjung Mas, Semarang

\begin{tabular}{lccr}
\hline \multicolumn{1}{c}{ Bulan } & $\begin{array}{c}\text { Kerang Kecil } \\
(3-4,59 \mathrm{~cm})\end{array}$ & $\begin{array}{c}\text { Kerang Sedang } \\
(4,6-6 \mathrm{~cm})\end{array}$ & $\begin{array}{c}\text { Kerang Besar } \\
(>6 \mathrm{~cm})\end{array}$ \\
\hline Juli & 9039,70 & 8958,43 & 8650,19 \\
September & 21100,00 & 21541,79 & 24838,81 \\
Oktober & 3471,86 & 3486,23 & 3271,26 \\
November & 12098,51 & 12098,51 & 10058,21 \\
\hline
\end{tabular}

Tabel 4 Faktor biokonsentrasi kerang hijau (Perna viridis) dan sedimen (FKB o-s) pada bulan Juli, September, Oktober, dan November dari Perairan Tanjung Mas, Semarang

\begin{tabular}{lccc}
\hline \multicolumn{1}{c}{ Bulan } & $\begin{array}{c}\text { Kerang Kecil } \\
(3-4,59 \mathrm{~cm})\end{array}$ & $\begin{array}{c}\text { Kerang Sedang } \\
(4,6-6 \mathrm{~cm})\end{array}$ & $\begin{array}{c}\text { Kerang Besar } \\
(>6 \mathrm{~cm})\end{array}$ \\
\hline Juli & 0,025 & 0,024 & 0,024 \\
September & 0,282 & 0,287 & 0,332 \\
Oktober & 9,647 & 9,687 & 9,090 \\
November & 0,013 & 0,012 & 0,010 \\
\hline
\end{tabular}




\section{DAFTAR PUSTAKA}

Ahmed Q, Bat L, Yousuf F. 2015. Accumulation of heavy metals in tissues of long tail tuna from karachi fish harbour Pakistan. Aquatic Science And Technology. 3(1): 103-115. https://doi.org/ 10.5296/ast.v3i1.6814

Amansyah M, Syarif AN. 2014. Analisis kandungan logam berat pada kerang anadara dari daerah Hilir Sungai Jeneberang. Al-sihah: Public Health Science Journal. 16(2): 85-98.

Amelia F, Ismarti, Ramses, Rozirwan. 2019. Biokonsentrasi faktor logam berat pada kerang dari Perairan Batam Kepulauan Riau Indonesia. Jurnal Kimia dan Pendidikan. 4(2): 152-163. https:// doi.org/10.30870/educhemia.v4i2.5529

Amriani, Hendrarto B, Hadiyarto B. 2011. Bioakumulasi logam berat timbal $(\mathrm{Pb})$ dan seng $(\mathrm{Zn})$ pada kerang darah (Anadara granosa L.) dan kerang bakau (Polymesoda bengalensis L.) di perairan Teluk Kendari. Jurnal IImu Lingkungan.

APHA. 2012. Standard method for the examination of water and waste water. 22th edition. American Public Health Association. Washington DC (US): Environmental Protection Agency Press.

Budiawan, Febriana NH, Suseno H. 2019. Kemampuan kerang hijau (Perna viridis) mengakumulasi plutonium melalui jalur air laut. Jurnal Kimia Valensi. 5(1): 63-71. https:// doi.org/10.15408/jkv.v5i1.7730

FAO/WHO, 2004. Summary of Evaluations Performed by the Joint FAO/WHO Expert Committee on Food Additives (JECFA 1956-2003). (First Through Sixty First Meetings). ILSI Press International Life Sciences Institute.

Kamarati KFA, Ivanhoe AM, Sumaryono M. 2018. Kandungan logam berat besi $(\mathrm{Fe})$, timbal $(\mathrm{Pb})$ dan mangan (Mn) pada air Sungai Santan. Jurnal Penelitian Ekosistem Dipterokarpa. 4(1):49-56.

LaGrega MD, Buckingham PL, Evans, JC. 2001. Hazardous Waste Management. 2 nd edition. Boston (MA): McGraw-Hill.

Liliandri P, Aunurohim. 2013. Kecepatan filtrasi kerang hijau Perna viridis L. terhadap Chaetoceros sp dalam media logam tercemar kadmium. Jurnal Sains Dan Seni Pomits. 2(2): 149-154.

Mirawati F, Supriyantini E, Nuraini RAT. 2016. Kandungan logam berat timbal $(\mathrm{Pb})$ pada air, sedimen, dan kerang hijau (Perna viridis) di Perairan Trimulyo dan Mangunharjo Semarang. Buletin Oseanografi Marina. 5(2): 121-126. https:// doi.org/10.14710/buloma.v5i2.15731

Permanawati Y, Zuraida R, Ibrahim A. 2013. Kandungan logam berat $(\mathrm{Cu}, \mathrm{Pb}, \mathrm{Zn}, \mathrm{Cd}$, Dan $\mathrm{Cr})$ dalam air dan sedimen di perairan Teluk Jakarta. Jurnal Geologi Kelautan. 11(1): 9-16.

Pratama AG, Pribadi R, Maslukah L. 2012. Kandungan logam berat $\mathrm{Pb}$ dan $\mathrm{Fe}$ pada air, sedimen, dan kerang hijau (Perna viridis) di Sungai Tapak Kelurahan Tugurejo Kecamatan Tugu Kota Semarang. Journal of Marine Research. 1(1): 118122.

Qamariyah N, Yanti R. 2018. Uji kuantitatif kadar zat besi dalam tumbuhan kelakai dan produk olahannya. Jurnal Surya Medika. 3(2): 32-40.

Rahma DA, Afiati N, Rudiyanti S. 2017. Analisis biokonsentrasi kadmium (Cd) pada kerang hijau (Perna viridis) di perairan Poncol Desa Bulu Kabupaten Jepara Jawa Tengah. Journal Of Maquares. 6(1): 10-16.

Rayyan MF, Yona D, Sari SHJ. 2019. Health risk assessments of heavy metals of Perna viridis from Banyuurip waters in Ujung Pangkah Gresik. Jurnal of Fisheries and Marine Science. 3(2): 135-142. https://doi.org/10.21776/ub.jfmr.2019.003.02.2

Rochyatun E, Kaisupy MT, Rozak A. 2006. Distribusi logam berat dalam air dan sedimen di Perairan Muara Sungai Cisadane. Makara Sains. 10(1): 3540. https://doi.org/10.7454/mss.v10i1.151

Rudiyanti S. 2012. Biokonsentrasi kerang darah (Anadara granosa Linn) terhadap logam berat cadmium (Cd) yang terkandung dalam media pemeliharaan yang berasal dari Perairan Kaliwungu Kendal. Di dalam: Priyanto S. Seminar Nasional Semarang Perikanan Expo. 2009; Semarang, Indonesia. Semarang (ID): Universitas Diponegoro. hlm 184-195.

[SNI] Standar Nasional Indonesia. 2009. Batas Maksimum Cemaran Logam Berat dalam Pangan. Jakarta(ID): Badan Standardisasi Nasional.

Supriyantini E, Endarwati H. 2015. Kandungan logam berat besi (Fe) pada air, sedimen, dan kerang hijau (Perna viridis L.) di perairan Tanjung Mas Semarang. Jurnal Kelautan Tropis. 18(1): 38-45.

Suryaningsih, Said I, Rahman N. 2018. Analisis kadar kalsium $(\mathrm{Ca})$ dan besi $(\mathrm{Fe})$ dalam kangkung air (Ipomeae Aquatica Forsk) dan kangkung darat (Ipomeae Reptan Forsk) asal palu. J Akademika Kim. 7(3): 140-145.

Tantanasarit C, Babel S, Englande AJ, Meksumpun S. 2013. Influence of size and density on filtration rate modeling and nutrient uptake by green mussel (Perna viridis). Marine pollution bulletin. 68(1): 3845.

Wulandari SY. 2012. Status Perairan Banjir Kanal Timur Semarang Ditinjau dari Kadar Logam Berat Chromium dalam Air, Sedimen dan Jaringan Lunak Kerang Darah (Anadara granosa). Buletin Oseanografi Marina. 1(1): 1-7. 